(12)

\title{
変形性膝関節症の進行が歩行中の膝関節キネマ ティクス・キネティクスに及ぼす影響
}

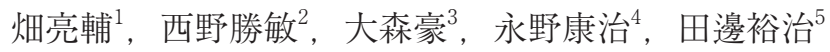 \\ 1 新潟大学大学院自然科学研究科, 2 新潟県健康づくり・スポーツ医科学センター, \\ 3 新潟医療福祉大学健康スポーツ学科, ${ }^{4}$ 日本女子体育大学スポーツ健康学科, \\ 5 新潟大学工学部機械システム工学科
}

\begin{abstract}
要旨 変形性膝関節症（滕 OA）は, 膝関節の力学的環境の異常によって引き起こされる。この 進行を予防及び治療するためには, 歩行などの荷重下動的状況に抢いて膝 OA に作用する力学 的要因を明らかにする必要がある, 本研究の目的は, 様々な膝 OA 進行度を有する対象の歩行 中に抢ける膝関節を運動学・動力学的に分析することで膝 OA 進行に作用する力学的要因を検 討することである。対象は成人 62 名 69 膝とし, 滕 OA の進行別に OA 無 : 26 滕, 初期 OA： 16 膝, 中高度 $\mathrm{OA} ： 27$ 滕に分類した. 対象の歩行をモーション・キャプチャー・システムで測 定し, 二方向 X 線撮影と三次元再構成法を用いて大腿脛骨運動を推定した. さらに, 滕の動力 学的要素として下肢荷重線の脛骨近位関節面への通過点（LAK point）や Joint reaction force, Joint moment を分析した. 中高度 OA の歩行立脚期では, 膝屈曲量と前後変位量, LAK point の前後移動量が有意に減少していたが, Joint reaction forceの内外側変化量は有意に増加してい た. 初期 OA でも, LAK pointの前後移動量が減じている兆候が見られた。ささらに, 中高度 OA の LAK point は荷重応答期に内側へ急激に移動している傾向があった，歩行立脚期では膝 OA の進行に伴って上半身の重量が脛骨関節面の局所に集中しており, さらに膝関節内外側方向への 力が増大していた。 これらの力学的変化が膝 $\mathrm{OA}$ 進行に作用する可能性が示唆された.

キーワード : 変形性膝関節症, 歩行, 膝関節, 運動学, 運動力学
\end{abstract}

\section{1.はじめに}

近年の日本では, 65 歳以上の高齢者数が急増し ており，内閣府公表の高齢社会白書の平成 26 年度 版によると, 高齢者人口は過去最高の 3,190 万人と なり, 高齢化率も $25.1 \%$ となった ${ }^{1)}$. それに伴い, 日本人の総疾患数に対する高齢者特有の疾患数が占
める割合も増加している。

高齢者特有の整形外科的疾患のひとつとして変形 性膝関節症（knee osteoarthritis：膝 OA）がある. 膝 $\mathrm{OA}$ は, 膝関節の力学的環境の異常が原因で生 じる関節軟骨の摩耗や欠損によって疼痛や関節可動 域の制限, 腫脹等が引き起こされる疾患であり, 加 齢や女性, 肥満等が危険因子とされている OA は患者の日常生活動作や quality of life (QOL) 
130 バイオメカニズム 23

に影響を及ぼすため, 膝 OA の予防や治療の検討 には膝関節に作用する力学的要因を詳細に分析する ことが重要である.

これまで膝 OA の進行が膝関節に作用する力学 的要因を歩行や階段昇降等の荷重下動的場面で分析 するために，様々な方法が開発されてきた．X線透 視撮影装置と三次元骨モデルを用いて膝 OA の運 動をin vivoに分析している報告 ${ }^{4)}$ では, 健常膝で 見られている特徵が消失する異常運動を検出してお り, その原因として膝関節面の変性や筋肉・勒帯等 の支持組織の異常だと指摘しているが, 力学的な環 境変化の分析までには至っていない，in vitroでは， ゴニオメータやモーション・キャプチャー・システ 厶等の対外装置を用いた歩行分析が多数報告されて いる ${ }^{5 \sim 8)}$. その多くが Joint moment 等の動力学的 変化に注目しているが, 下肢骨の特徴等の対象個々 の背景を考慮した報告は非常に少ない，対象個々の 情報を組み入れて歩行中の膝関節に作用する力学的 要因を分析した報告 ${ }^{6.7)}$ も散見されているが，それ を用いて膝 $\mathrm{OA}$ 進行の集団分析を行った報告は皆 無である.

我々も対象個々の下肢骨の情報を組み入れた荷重 下動的場面に扮ける大腿脛骨運動の分析法 ${ }^{8)}$ を開発 しており,これを用いて滕 OA が無い方から様々 な膝 $\mathrm{OA}$ 進行度を有する方まで数多くの対象の歩 行動作を分析してきた。本研究の目的は, さらに動 力学的分析法を組み入れて歩行動作を運動学・動力 学的に分析することで, 膝 OA 進行が膝関節に作 用する力学的要因を検討することである，本研究の 仮説は, 膝 OA の進行初期からでも運動学・動力 学的に変化があり, 進行が高くなるとその変化が増 加することである.

\section{2. 対象と方法}

\section{1 対象}

本研究は, 新潟県健康づくり・スポーツ医科学セ ンターの倫理審査委員会においてへルシンキ宣言に 基づいた厳密な審査によって承認された後に実施し た（承認番号 22）。
対象は，次の条件に該当する者を募集した：(1) 20 歳以上；(2) 補助具無しで自立歩行が可能；(3) 人工膝関節置換術等の膝関節の力学的環境を変える 手術歴が無い. その結果, 62 名 69 膝（男性 23 名, 女性 39 名）が集まり, 事前に趣旨を十分に説明し, 同意を得た後に測定した.

測定前には，膝の痛みを計るVAS scale と変形 性膝関節症患者機能評価尺度 $\mathrm{JKOM}^{9}$ を調査した。 JKOM は 25 問から成り, 高得点ほど疼痛の悪化や 身体的不具合を示す (最大 100 点). 膝 OA の進行 度は, 滕正面 X 線像から Kellgren-Lawrence scale $^{10)}$ に準じて整形外科医師が診断した。その結果, grade- 0 が 12 膝, grade-I が 14 膝, grade-II が 16 膝, grade-III が 20 膝, grade-IV が 7 膝であり, grade-II 以降は全て内側型膝 OA であった。本研究 では膝 OA の進行度を次の 3 群に分類した：(1) grade-0 と I を OA 無 ; (2) grade-II を初期 OA ; (3) grade-III と IV を中高度 OA.

\section{2 歩行の 3 次元撮影}

対象の全身に $15 \mathrm{~mm}$ 径の反射マーカを 34 個貼付 した. 特に, 大腿部上に貼付した 12 個のマーカと 脛部上に貼付した 8 個のマーカは, 貼付位置を X 線画像上で検出できるようにその中心に $1 \mathrm{~mm}$ 径鋼 球を入れた特製マーカを用いた。

対象には $8 \mathrm{~m}$ 長の直線路を自身の通常歩行速度 で歩かせた，歩行開始から一定の歩行速度に到達す ると考えられる直線路の中央部を測定空間とし，そ の空間内に歩行空間座標系 $\Sigma_{\mathrm{W}}$ を設定した. 歩行中 のマーカの三次元位置の検出には, モーション・キ ヤプチャー・システム VICON(Vicon Motion Systems, UK）を用いた（サンプリング周波数 $120 \mathrm{~Hz}$ ) 。 検出した大腿部と脛部のマーカ群の三次元位置は, 図1に示すように $\Sigma_{\mathrm{W}}$ に関してそれぞれ $\mathrm{q}_{\mathrm{WT}}(t)$ と $\mathrm{q}_{\mathrm{wS}}(t)$ として定義し $(t$ は計測サンプル), さらに 四次のバターワースフィルタ $(7 \mathrm{~Hz})$ で平滑化した また, 歩行中に生じる床反力は, 地面に埋設した 6 枚のフォースプレート (Kistler Co., Switzerland) を用いてサンプリング周期 $240 \mathrm{~Hz}$ で計測した。 歩行計測直後にマーカを貼付した状態で対象を立 


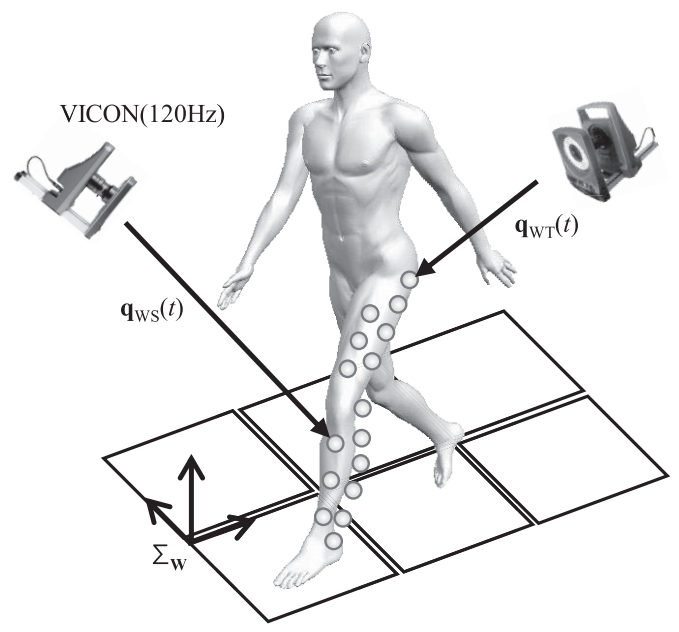

図 1 歩行の 3 次元撮影

位静止させて下肢全長の正面と 60 度斜角の二方向 から X 線撮影した ${ }^{11)}$. X 線像上のマーカ位置をデ ジタイズし，三次元再構成法によってその三次元位 置を推定した。三次元再構成法で用いる射影変換行 列は, 撮影前のキャリブレーションで決定した ${ }^{11)}$. さらに, マーカと共にX 線像に撮像されている下 肢骨の輪郭に対象の下肢を CT 撮影して解剖学的座 標系を設定した三次元骨モデルを重ね合わせること で，下肢骨の解剖学的座標系に関するマーカの三次 元位置データとして表した（図 2)。この重ね合わ せには2D/3D image matching technique を用いて おり，その誤差は $0.5 \mathrm{~mm}$ かつ 0.6 度以内であっ た ${ }^{11)}$ 。大腿部のマーカは, 大腿骨座標系 $\Sigma_{\mathrm{F}}$ に関す る位置 $\mathbf{p}_{\mathrm{F}}$ として表した，脛部のマーカは，脛骨座 標系 $\Sigma_{\mathrm{T}}$ に関する位置 $\mathbf{p}_{\mathrm{T}}$ として表した。

分析対象脚の歩行動作は, 1 歩行を次の 4 つの特 徵的場面に分類した：初期接地（Initial contact： IC)；足底全接地（Foot plant：FP）；踵挙上（Heel rise : HR) ; 足趾離地 (Toe off : TO). さらに, 相 分類として最初の IC から TO までを立脚期, TO から次の ICまでを遊脚期と定義した。

\section{3 歩行中の大腿脛骨運動の推定}

歩行中の計測サンプル $t$ における大腿骨座標系 $\Sigma_{\mathrm{F}}$ と歩行空間座標系 $\Sigma_{\mathrm{W}}$ との位置関係を $\Sigma_{\mathrm{F}}$ から $\Sigma_{\mathrm{W}}$ への座標変換行列 $\mathrm{T}_{\mathrm{FW}}(t)$ として表す。この

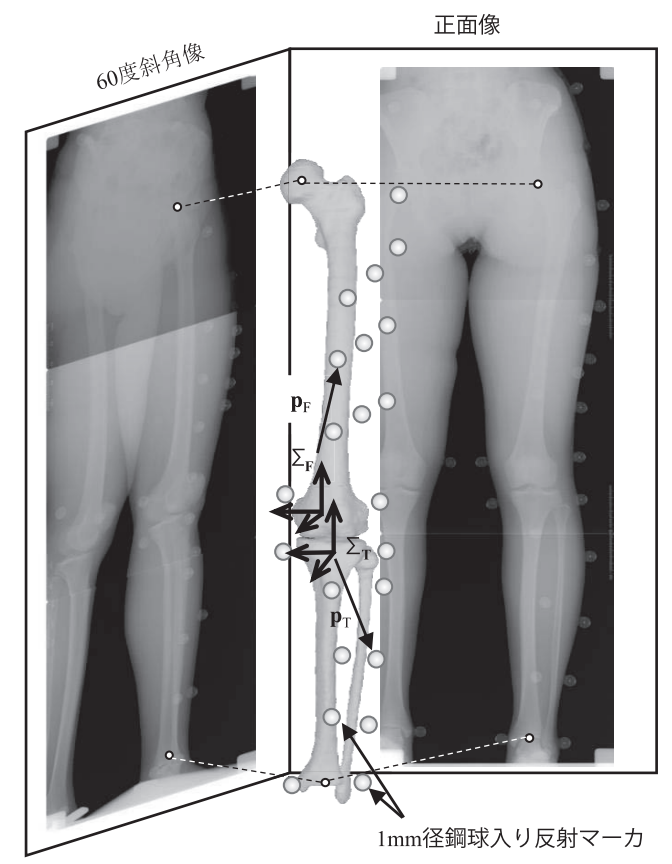

図 2 下肢の二方向 $\mathrm{X}$ 線撮影像によるマーカ位置の推定

$\mathrm{T}_{\mathrm{FW}}(t)$ は, $3 \times 3$ の回転行列と $3 \times 1$ の並進ベクト ルを含む $4 \times 4$ の同次行列を意味し, 大腿部上のマ 一カの位置デー夕 $\mathrm{p}_{\mathrm{F}}$ と $\mathrm{q}_{\mathrm{WT}}(t)$ との関係式の最小二 乗推定によって得られる ${ }^{8)}$. 脛骨座標系 $\Sigma_{\mathrm{T}}$ から $\Sigma_{\mathrm{W}}$ への座標変換行列 $\mathrm{T}_{\mathrm{TW}}(t)$ も同様の手順で推定でき る.これらの座標変換行列 $\mathrm{T}_{\mathrm{FW}}(t)$ と $\mathrm{T}_{\mathrm{FW}}(t)$ を式 (1) のように合成することによって， $\Sigma_{\mathrm{F}}$ から $\Sigma_{\mathrm{T}}$ への座標変換行列 $\mathrm{T}_{\mathrm{FT}}(t)$ を得ることができる.

$$
\mathrm{T}_{\mathrm{FT}}(t)=\mathrm{T}_{\mathrm{TW}}(t) \cdot \mathrm{T}_{\mathrm{FW}}(t)-1
$$

この $\mathrm{T}_{\mathrm{FT}}(t)$ を大腿骨と脛骨の三次元骨モデルに適 用することで, 歩行中の計測サンプル $t$ に抢ける大 腿骨と脛骨の相対的位置関係を推定でき，この連続 值によって歩行中の大腿脛骨の相対運動を表すこと ができる8).

歩行中の大腿脛骨の相対運動について, Grood ら の方法 ${ }^{12)}$ に準じて回転と並進の成分を抽出した。回 転成分は, 屈曲 $(+) /$ 伸展 $(-)$, 外反 $(+) /$ 内反 $(-)$, 内旋 $(+) /$ 外旋 $(-)$, 並進成分は, 外側 $(+) /$ 内側 $(-)$, 前方 $(+) /$ 後方 $(-)$ とした. なお, 本研究では, 1 歩行周期に扔ける各成分の変 
化量（最高值と最低值との差）で評価した。また, その他の評価項目として, 歩行速度とその身長比も 求めた。

\section{4 歩行中の膝関節の力学的分析}

歩行立脚期は膝関節に大きな力が負荷される期間 であるため, 次のように膝関節にかかる負荷を動力 学的に分析した。

歩行立脚期の計測サンプル $t$ における大腿骨と脛 骨の位置関係から大腿骨頭と脛骨遠位関節面中心と を結ぶ線を求め, これを上半身の重量が下肢に荷重 されるという意味の下肢荷重線 (Loading axis of knee：LAK）と定義した。ささらに LAK が脛骨座 標系 xy 面と交差する点を LAK point として算出し た (図 $3 \mathrm{a})^{8)}$ 。この LAK point を歩行立脚期におい て全て得ることで脛骨座標系 xy 面と近似する位置 にある脛骨近位関節面における LAK pointの軌跡 が求められる。これを脛骨座標系の内外側方向への 移動量と前後方向への移動量の 2 つの成分に分け, 対象の脛骨近位関節面の内側面の幅 (MCW) と前 後方向の長さ (APW) でそれぞれ標準化した（図 $3 \mathrm{~b})^{8)}$. さらに, LAK point の軌跡長やそれを移動 面積で除して標準化した軌跡長移動面積比も評価し た.

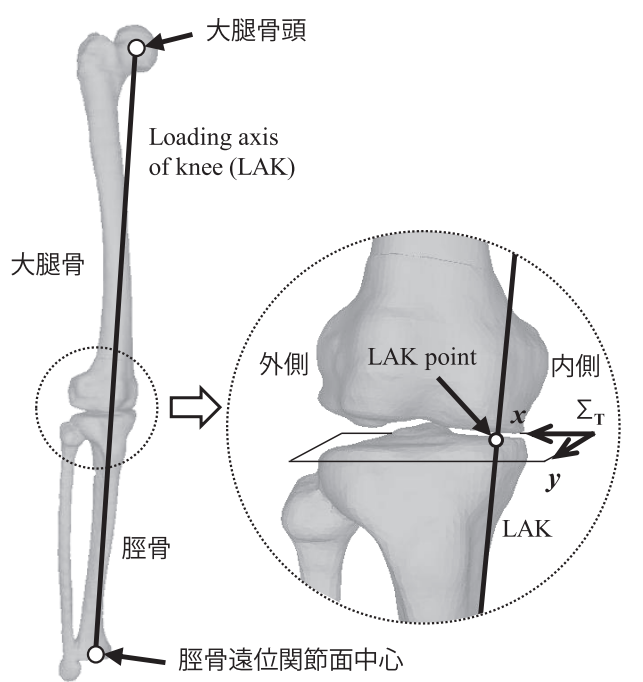

(a) LAK point $の$ 算出
膝関節に生じる Joint reaction force と Joint moment を逆動力学的手法によって次のように求め $た^{13)}$. 下肢の大腿部, 脛部, 足部の各体節は剛体と し，体節間は並進がない Boll-and-socket joint で接 続されている剛体リンクモデルとして定義した。計 測サンプル $t$ において, 体節の近位関節で生じる Joint reaction force を $F_{\text {prox }}(t)$, 隣接する遠位の体 節から伝わる Joint reaction force を $F_{\text {dist }}(t)$ とする 体節の質量を $m_{\mathrm{seg}}$, 体節の重心位置を $C O G_{\mathrm{seg}}(t)$ と し, これらは身体部分の慣性特性 ${ }^{14,15)}$ に準じて求め た、時間の二階微分による体節の重心における加速 度を $C \ddot{O} G_{\mathrm{seg}}(t)$ とすると, 式（2）による Newton の運動方程式に基づいて $\boldsymbol{F}_{\mathrm{prox}}(t)$ を推定した。

$$
\boldsymbol{F}_{\mathrm{prox}}(t)=m_{\mathrm{seg}} \cdot \boldsymbol{C} \ddot{O} \boldsymbol{G}_{\mathrm{seg}}(t)-m_{\mathrm{seg}} \cdot \boldsymbol{g}-\boldsymbol{F}_{\mathrm{dist}}(t)
$$

ここで, $\boldsymbol{g}$ は重力加速度とし，体節が足部の場合は $F_{\text {dist }}(t)$ をフォースプレートから得られる床反力值 とした。

さらに，計測サンプル $t$ において，ある体節の近 位関節で生じる Joint moment を $\boldsymbol{M}_{\mathrm{prox}}(t)$, 隣接す る遠位の体節で生じる Joint moment $\boldsymbol{M}_{\text {dist }}(t)$ と する，体節における角速度べクトルを $\omega_{\mathrm{seg}}(t)$ とす ると, 式（3）によるEularの運動方程式に基づい て $M_{\text {prox }}(t)$ を推定した.

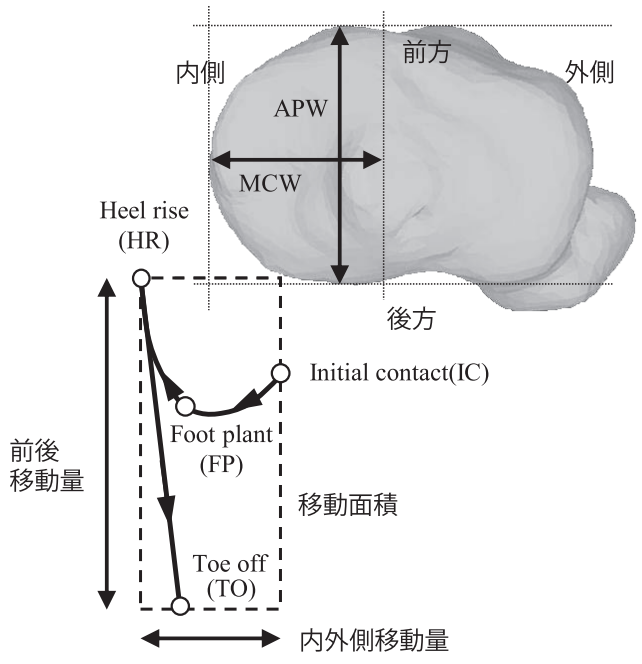

（b） LAK point の軌跡の評価

図 3 歩行立脚期における膝関節の動力学的分析 


$$
\begin{aligned}
\boldsymbol{M}_{\text {prox }}(t)= & \frac{d}{d t}\left(\boldsymbol{I}_{\text {seg }} \cdot \boldsymbol{\omega}_{\text {seg }}(t)\right)-\boldsymbol{M}_{\text {dist }}(t)-\boldsymbol{r}_{\text {dist }} \times \boldsymbol{F}_{\text {dist }}(t) \\
& -\boldsymbol{r}_{\text {prox }} \times \boldsymbol{F}_{\text {prox }}(t)
\end{aligned}
$$

ここで, $I_{\text {seg }}$ は体節の慣性モーメント ${ }^{14,15)}, r_{\text {prox }}$ と $r_{\text {dist }}$ は体節の重心から近位及び遠位関節中心までの 位置ベクトルとした。

膝関節に生じる Joint reaction force $(\mathrm{N})$ と Joint moment $(\mathrm{Nm})$ は対象のサイズに依存するため, Joint reaction force は対象の体重（N)で, Joint moment は対象の体重（N）と身長（m) で除して 標準化し，その単位をそれぞれ BW，HTBWで表 した。またここれらの力学的要素は， $\Sigma_{\mathrm{T}} に$ 基づい て表した。なお, 本研究で述べる Joint moment と は，外力によって関節を回転させる Moment に対 抗しょうと関節内部で反対方向に釣り合う Moment と定義した ${ }^{13)}$.

\section{5 統計分析}

膝 OA 進行度に拈ける 3 群間の差を one-way ANOVA と Tukey-Kramer testで比較した。有意 水準 $\alpha$ は $5 \%$ とした。

\section{3. 結果}

膝 OA 進行の各群の身体的背景を表 1 に示す. 加齢とともに膝 OA が進行しており, 肥満の指標 のひとつである BMI について中高度 OA は他の群
に比して有意に増加していた，中高度 OAのVAS と JKOM も他の群に比して有意に高く, 膝関節の 機能が明らかに悪化していた。

1 歩行周期における滕関節の運動学的項目を表 2 に示す。中高度 OA の歩行速度は OA 無と比して 有意に減少しており, その身長比も差が得られなか ったものの, 減じている傾向が見られた。膝関節角 度量について, 中高度 OA の屈曲量は他の群に比 して有意に減少していた。膝関節変位量について, 中高度 OA の前後変位量は OA 無しに比して有意 に減少していた。初期 OA も差が認められなかっ たが前後変位量が減じている傾向が見られた。

表 3 に歩行立脚期における滕関節の動力学的項目 を, 図 4 にLAK point の軌跡の代表例を示す. LAK point の内外側移動量は 3 群間で差が認めら れなかったが, 図 4 で示すように中高度 OA は IC

\begin{tabular}{|c|c|c|c|c|}
\hline \multirow{2}{*}{ 項 目 } & \multicolumn{3}{|c|}{ 膝 OA 進行度 } & \multirow{2}{*}{$p$-Value } \\
\hline & $\mathrm{OA}$ 無 & 初期 OA & 中高度 OA & \\
\hline 膝数 & 26 & 16 & 27 & \\
\hline 年齢[歳] & $39.2 \pm 19.1$ & $55.3 \pm 15.6$ & $67.7 \pm 9.7$ & $a^{* *}, b^{* *}, c^{*}$ \\
\hline 身長 $[\mathrm{cm}]$ & $164.5 \pm 9.4$ & $160.7 \pm 7.7$ & $155.6 \pm 6.4$ & $\mathrm{~b}^{* *}$ \\
\hline 体重 $[\mathrm{kg}]$ & $61.3 \pm 13.9$ & $58.6 \pm 6.8$ & $64.7 \pm 10.3$ & \\
\hline BMI & $22.4 \pm 3.3$ & $22.7 \pm 2.8$ & $26.7 \pm 4.0$ & $\mathrm{~b}^{* *}, \mathrm{c} * *$ \\
\hline VAS & $0.6 \pm 1.0$ & $1.1 \pm 1.5$ & $3.8 \pm 2.9$ & $\mathrm{~b}^{* *}, \mathrm{c} * *$ \\
\hline JKOM & $3.5 \pm 4.3$ & $7.6 \pm 8.3$ & $21.9 \pm 18.1$ & $\mathrm{~b}^{* *}, \mathrm{c}^{* *}$ \\
\hline
\end{tabular}

表 1 膝 $\mathrm{OA}$ 進行の各群の身体的背景

$\mathrm{a}$ : OA 無 vs 初期 OA, b : OA 無 vs 中高度 OA, c : 初期 $\mathrm{OA}$ vs 中高度 $\mathrm{OA}, *: p<0.05, * *: p<0.01$.

表 21 歩行周期における膝関節の運動学的項目

\begin{tabular}{llllll}
\hline \multirow{2}{*}{ 項 目 } & \multicolumn{3}{c}{ 滕 OA 進行度 } & \multirow{2}{*}{$p$-Value } \\
\cline { 3 - 5 } & & OA 無 & 初期 OA & 中高度 OA & \\
\hline 歩行速度 $[\mathrm{m} / \mathrm{s}]$ & $1.38 \pm 0.16$ & $1.33 \pm 0.16$ & $1.22 \pm 0.20$ & $\mathrm{~b}^{* *}$ \\
歩行速度身長比 $[\mathrm{m} / \mathrm{s} / \mathrm{m}]$ & & $0.84 \pm 0.10$ & $0.83 \pm 0.09$ & $0.78 \pm 0.13$ & \\
膝関節角度量 $[$ 度 $]$ & 屈曲 & $63.1 \pm 5.4$ & $64.3 \pm 5.1$ & $57.3 \pm 8.5$ & $\mathrm{~b}^{* *}, \mathrm{c}^{* *}$ \\
& 内外反 & $11.7 \pm 5.7$ & $11.6 \pm 7.4$ & $13.1 \pm 6.1$ & \\
& 内外旋 & $18.1 \pm 5.7$ & $15.0 \pm 5.2$ & $15.7 \pm 5.7$ & \\
膝関節変位量 $[\mathrm{mm}]$ & 内外側 & $0.29 \pm 0.14$ & $0.27 \pm 0.10$ & $0.23 \pm 0.10$ & \\
& 前後 & $1.34 \pm 0.37$ & $1.18 \pm 0.31$ & $1.04 \pm 0.30$ & $\mathrm{~b}^{* *}$ \\
\hline
\end{tabular}

$\mathrm{a}$ ：OA 無 vs 初期 OA, b : OA 無 vs 中高度 OA, c : 初期 OA vs 中高度 OA, $*: p<0.05, * *: p<0.01$. 
表 3 歩行立脚期における膝関節の動力学的項目

\begin{tabular}{|c|c|c|c|c|c|}
\hline \multirow{2}{*}{ 項 目 } & & \multicolumn{3}{|c|}{ 膝 OA 進行度 } & \multirow{2}{*}{$p$-Value } \\
\hline & & $\mathrm{OA}$ 無 & 初期 OA & 中高度 OA & \\
\hline \multirow[t]{4}{*}{ LAK-point analysis } & 内外側移動量 $[\mathrm{MCW}]$ & $0.29 \pm 0.14$ & $0.23 \pm 0.13$ & $0.31 \pm 0.17$ & \\
\hline & 前後移動量 [APW] & $2.76 \pm 0.44$ & $2.49 \pm 0.44$ & $2.34 \pm 0.68$ & $b^{*}$ \\
\hline & 軌跡長 $[\mathrm{mm}]$ & $190.5 \pm 36.5$ & $176.5 \pm 43.6$ & $157.9 \pm 46.8$ & $b^{*}$ \\
\hline & 軌跡長移動面積比 & $0.11 \pm 0.06$ & $0.15 \pm 0.09$ & $0.09 \pm 0.04$ & $\mathrm{c}^{*}$ \\
\hline \multirow[t]{3}{*}{ Joint reaction force $[\mathrm{BW}]$} & 内外側変化量 & $0.16 \pm 0.03$ & $0.16 \pm 0.04$ & $0.19 \pm 0.04$ & $b^{* *}, c^{*}$ \\
\hline & 前後変化量 & $0.53 \pm 0.06$ & $0.51 \pm 0.07$ & $0.47 \pm 0.06$ & $\mathrm{~b}^{* *}$ \\
\hline & 遠位方向 & $1.12 \pm 0.10$ & $1.07 \pm 0.12$ & $1.05 \pm 0.15$ & \\
\hline \multirow[t]{6}{*}{ Joint moment [HTBW] } & 屈曲 & $0.026 \pm 0.010$ & $0.022 \pm 0.012$ & $0.020 \pm 0.012$ & \\
\hline & 伸展 & $0.045 \pm 0.018$ & $0.045 \pm 0.016$ & $0.044 \pm 0.027$ & \\
\hline & 外反 & $0.022 \pm 0.008$ & $0.023 \pm 0.009$ & $0.031 \pm 0.014$ & $b^{*}$ \\
\hline & 内反 & $0.011 \pm 0.005$ & $0.009 \pm 0.006$ & $0.011 \pm 0.006$ & \\
\hline & 内旋 & $0.003 \pm 0.001$ & $0.003 \pm 0.002$ & $0.003 \pm 0.001$ & \\
\hline & 外旋 & $0.007 \pm 0.003$ & $0.007 \pm 0.004$ & $0.008 \pm 0.004$ & \\
\hline
\end{tabular}

$\mathrm{a} ： \mathrm{OA}$ 無 vs 初期 OA, b：OA 無 vs 中高度 OA, c : 初期 OA vs 中高度 OA, * : p<0.05, ** : p<0.01.

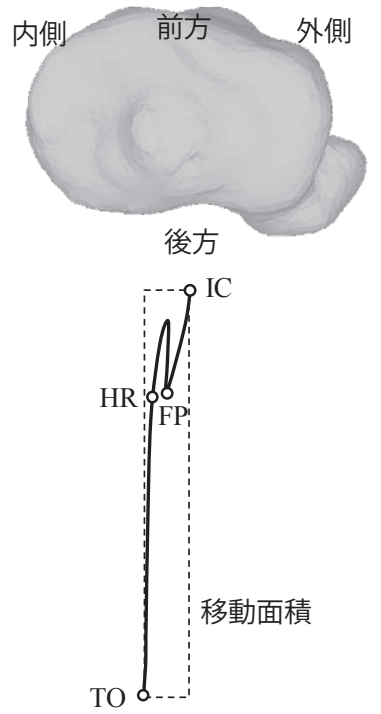

(a) $\mathrm{OA}$ 無

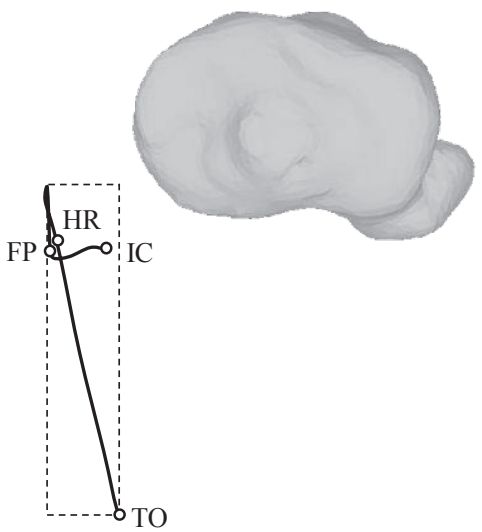

(b) 中高度 $\mathrm{OA}$

図 4 歩行立脚期に扔ける LAK point の軌跡の代表例

から FPにかけて内側へ急激に移動している例が多

くあった. LAK pointの前後移動量や軌跡長につ いて, 中高度 OA は OA 無に比して有意に減少し ており。初期 OA も差が認められなかったが減じ ている傾向が見られた．軌跡長移動面積比について
は, 中高度 OA は初期 OA に比して有意に減少し ていた。

図 5 に Joint reaction force, 図 6 にJoint moment の平均波形を示す.Joint reaction force の内側方向 と遠位方向の成分は, IC から FP の間に最大值が 

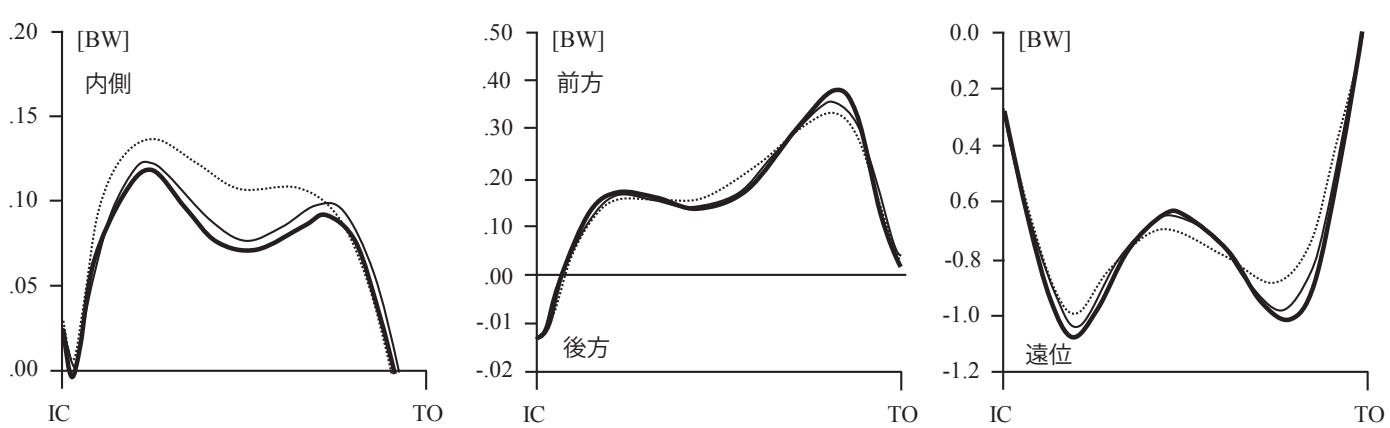

図 5 歩行立脚期の膝関節に生じる Joint reaction force の平均波形 太実線：OA 無L, 細実線: 初期 OA, 破線：中高度 OA.
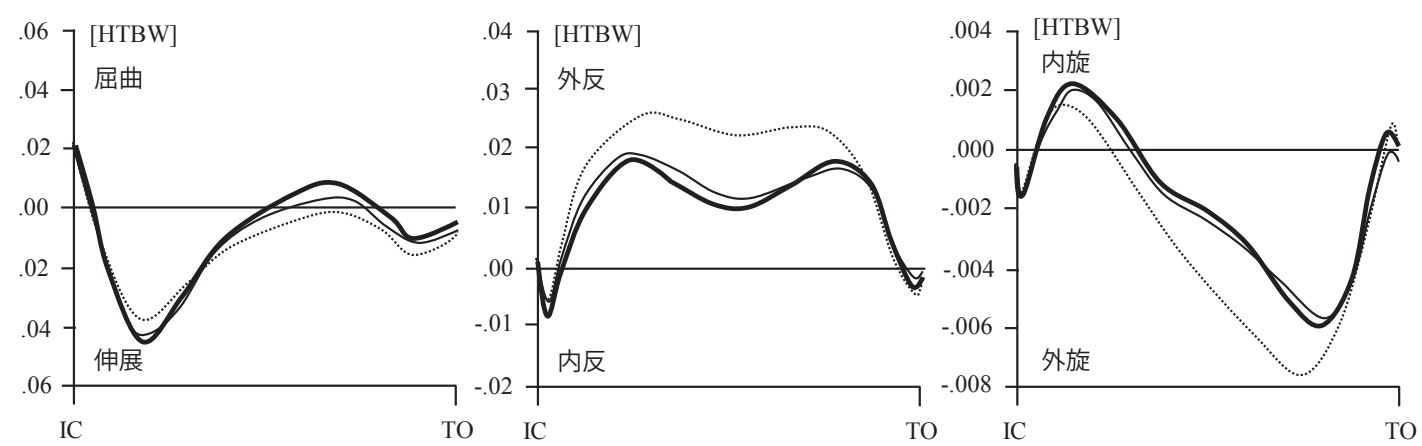

図 6 歩行立脚期の膝関節に生じる Joint moment の平均波形

太実線：OA 無し, 細実線 : 初期 OA, 破線 : 中高度 OA.

観察された。 中高度 OAの Joint reaction force に ついて, 内外側変化量が他の群に比して有意に増加 している一方, 前後変化量や遠位方向は有意に減少 していた. Joint momentについては, 中高度 OA の外反が他の群に比して有意に増加していた。

\section{4. 考察}

表 1 に示した滕 OA 進行の各群の身体的背景で は, 中高度 OA はほぼ全ての項目で他の群に比し て有意な差が認められたが, 初期 OAについては OA 無との差がほとんど認められなかった。初期 OA の JKOM を見ても OA 無と比して標準偏差が 大きくなっていることから, 本研究における初期 OA 群は, X 線上での診断では骨形態の変化が現れ 始めていたが, 他の群に比して対象数が少ない状況 であるにもかかわらず, 膝関節の機能についてはば らつきが大きかったことが分かる。従って，初期
OAの歩行動作もばらつきが大きかった可能性が示 唆される。

歩行中の運動学的項目について, 中高度 OAの 歩行速度は減少しており, また滕関節屈曲量及び前 後変位量も減少していた。これらと同様の結果を述 べている報告は過去にも多数見られている。これら を減じさせる要因として, 屈曲拘縮等の関節機能の 低減や疼痛による制限等, 膝 OA 特有の症状が考 えられる,さらに, 前後変位量についても膝関節屈 曲量の減少に伴って膝関節の運動範囲が小さくなっ たことから，それに関連して減少したものと考えら れる。初期 OA の膝関節運動について, OA 無と比 して有意な差は認められなかったが, 前後変位量に ついては減じている兆候が見られた。初期 OAの 背景のばらつきが原因なのか, 屈曲量の減少は見ら れなかったが, 初期 OAに扔ける前後移動量の減 少の兆候については, さらなる詳しい検討が必要で ある。 
歩行立脚期における動力学的項目のひとつとして, 我々はLAK point を分析した. LAK pointは上半 身の重量が膝関節面の荷重環境に作用させる力点と して示したものであり，動的場面にこの連続值を分 析することで脛骨関節面にかかる荷重の位置と方向 を把握できる. 本研究では, LAK pointの移動を 脛骨関節面に対して内外側と前後の 2 つ成分で表 し, 立脚期に扔ける軌道長と軌道長移動面積比も評 価した。軌道長移動面積比は, 荷重が脛骨関節面の 局所に集中しているかどうかを表すもので，これが 小さい場合は脛骨関節面への負担増を意味する。

本研究の結果から, 歩行立脚期における LAK point の内外側移動量は差が無かったが, 前後移動 量と軌跡長では中高度 OA は OA 無に比して有意 に減少していた。これは, 膝関節の前後変位量でも 同じ結果を得ていた。 また, 軌跡長移動面積比でも 中高度 OA は初期 OA に比して有意に減少してい た。これらの結果から, 中高度 OA は他に比して 荷重が脛骨関節面の局所に集中している可能性を示 唆していた。さらに, LAK pointの移動を脛骨関 節面に表した図 4 を見ると, 中高度 OA は IC から FP の間, いわゆる荷重応答期で内側へ急激に移動 する特徵が見られた。これは相対的には膝関節が外 側へ移動していることを表している。荷重応答期に おいて膌 $\mathrm{OA}$ 患者に現れる特徵として, 膌の急激 な外側移動，いわゆる Thrust ${ }^{5,6,16)}$ がある. Thrust は, これまで歩行正面からの視診で検出しており，

Thrust が生じる対象は立脚期において内反角速度 の増加や膝正面上での Joint moment の増加が認め られる報告 ${ }^{16)}$ もあことから, 膝関節の運動学・動 力学的変化を示す指標として用いられている. 従っ て, Thrust と今回得た LAK point の内側移動は相 互に関係していると考えられ，今後LAK pointの 分析によって Thrust の出現要因を検討できる可能 性が示唆された。また, 初期 OA について, LAK point の前後移動量と軌跡長が OA 無に比して減少 している傾向があったことから，荷重が脛骨関節面 の局所に集中し始めている兆候が見られた。

歩行立脚期の膝関節に生じる Joint reaction force について, 内側方向と遠位方向の最大值が 3 群とも
に荷重応答期に観察されたことから，この期間に膝 関節には最大の内側方向へのせん断力と圧縮力が加 わっていたことを意味している。 さらに, 中高度 OA の内外側変化量が他に比して増加している一方 で前後変化量が減少していたことから, 中高度 OA の膝関節では相対的に内外側方向への力が増加して いる可能性が示唆された。膝関節の関節面形状や軟 骨, さらに勒帯は, 内外側方向への力に対して支持 できない構造を有しているため, この内外側方向へ の力の増加が関節面の磨耗や欠損に大きく関与する 可能性が考えられる. Joint momentについては, 中高度 OA の外反が他に比して増加しており, こ れは過去の文献6)でも矛盾していなかった。

本研究から, 中高度 $\mathrm{OA}$ の滕関節の運動学・動 力学的環境が他に比して大きく異なっていることが 分かり, 特に立脚初期の荷重応答期における膝関節 内外側及び前後方向の力学的変化が膝 $\mathrm{OA}$ 進行に 作用する可能性が示唆された。この要因として関節 面の変性が考えられるが，下肢筋力が膝関節運動の 安定性に関与するという報告 ${ }^{17)}$ から見ても下肢筋力 の低下も考えられる。ささらに, 初期 OA では今回 の集団の背景のばらつきが大きかったために明らか な変化を検出できなかったものの, 動力学的変化の 兆候が見られたことは今後の分析で注目する要素と して期待できる。

本研究の課題として，まず我々の方法に含まれる 誤差の検討である. 運動測定が対外式であるため, 誤差の大部分は皮膚表面と骨との間の動摇誤差, い わゆる skin movement artifactである。これは筋力 が低下する高齢者や脂肪が多い女性ほど大きいと考 えられるため, 高齢かつ女性に多い膝 OA 患者で は大きく依存することが明白である。我々が開発し た方法には Skin movement artifactを低減させる 手法 ${ }^{18)}$ が内在しているものの, 実際の大腿脛骨運動 にどれだけ追随できているかは今後詳しく検証する 必要がある, 次に, 実際の膝関節面形状を考慮して 膝関節の運動学及び動力学を分析することである.

特に, 実際の膝関節は荷重を脛骨関節面の内側と外 側に受けて運動しているため, 膝 OA 進行に作用 する力学的因子を解明するためには膝関節面への接 
触状態の把握が不可欠である. 最後に膝関節の力学 的環境を変化させる筋力等の支持組織や他の下肢関 節との関連性の検証である.

\section{謝辞}

本研究は, 公益財団法人ミズノスポーツ振興財団

の 2015 年度研究助成を受けたものである.

\section{参考文献}

1）内閣府：平成 26 年版高齢社会白書, http://www8.cao. go.jp/kourei/whitepaper/w-2014/zenbun/26pdf_index. html

2) Shiozaki, H., Koga, Y., Omori, G. and Tamaki, M.: Obesity and osteoarthritis of the knee in women: results from the Matsudai Knee Osteoarthritis survey, Knee, 6 , 189-192, (1999).

3) Aoda, H., Nakamura, K., Omori, G., Koga, Y., Akazawa, K. and Yamamoto, M.: Independent predictors of knee osteoarthritis in an elderly Japanese population: A multivariate analysis, Acta Medica et Biologica, 54, 33-41, (2006).

4) Hamai, S., Moro-oka, T., Miura, H., Shimoto, T., Higaki, H., Fregly, B.J., Iwamoto, Y. and Banks, S.A.: Knee kinematics in medial osteoarthritis during in vivo weightbearing activities, J Orthop Res, 27, 1555-1561, (2009).

5) Kito, N., Shinkoda, K., Yamasaki, T., Kanemura, N., Anan, M., Okanishi, N., Ozawa, J. and Moriyama, H.: Contribution of knee adduction moment impulse to pain and disability in Japanese women with medial knee osteoarthritis, Clin Biomech, 25, 914-919, (2010).

6) Koga, Y:: Three-dimensional knee motion analysis for the pathogenesis knee osteoarthritis, Biomed Mater Eng, 8, 196-205, (1998).

7) Kawakami, H., Sugano, N., Yonenobu, K., Yoshikawa, H., Ochi, T., Hattori, A. and Suzuki, N.: Gait analysis system for assessment of dynamic loading axis of the knee, Gait Posture, 21, 125-130, (2005).

8) Nishino, K., Omori, G., Koga, K., Kobayashi. K., Sakamoto, M., Tanabe, Y., Tanaka, M. and Arakawa, M.:
Three-dimensional dynamic analysis of knee joint during gait in medial knee osteoarthritis using loading axis of knee, Gait and Posture, 42, 127-132, (2015).

9) Akai, M., Doi, T., Fujino, K., Iwaya, T., Kurosawa, H. and Nasu, T.: An outcome measure for Japanese people with knee osteoarthritis, J Rheumatol, 32, 1524-1532, (2005).

10) Kellgren, J.H. and Lawrence, J.S.: Radiological assessment of osteo-arthrosis, Ann Rheum Dis, 16, 494-502, (1957).

11) Kobayashi, K., Sakamoto, M., Tanabe, Y., Ariumi, A., Sato, T., Omori, G. and Koga, Y.: Automated image registration for assessing three-dimensional alignment of entire lower extremity and implant position using biplane radiography, J Biomech, 42, 2818-2822, (2009).

12) Grood, E.S. and Suntay, W.J.: A joint coordinate system for the clinical description of three-dimensional motions: application to the knee, J Biomech Eng, 105, 136-144, (1983).

13）西野勝敏, 大熊伸江 : バドミントン競技のフロントコー ト・フォアハンド・リフト動作における踏込脚の動力学 的分析, スポーツ・アンド・ヒューマン・ダイナミクス 講演論文集, (2014).

14）岡田英孝, 阿江通良, 藤井範久, 森丘保典 : 日本人高齢 者の身体部分慣性特性，バイオメカニズム，13，125139, (1996).

15）阿江通良：Kinematics と Kinetics をつなぐ身体部分慣 性係数一その測定法と係数の比較, バイオメカニクス研 究, 1, 51-62, (1997).

16) Chang, A.H., Chmiel, J.S., Moisio, K.C., Almagor, O., Zhang, Y., Cahue, S. and Sharma, L.: Varus thrust and knee frontal plane dynamic motion in persons with knee osteoarthritis, Osteoarthritis Cartilage, 21, 16681673, (2013).

17) van der Esch, M., Steultjens, M., Harlaar, J., Wolterbeek, N., Knol, D.L., and Dekker, J.: Knee varus-valgus motion during gait -a measure of joint stability in patients with osteoarthritis?, Osteoarthritis Cartilage, 16, 522-525, (2008).

18) Andriacchi, T.P., Alexander E.J., Toney, M.K., Dyrby, C. and Sum, J.: A point cluster method for in vivo motion analysis: Applied to study of knee kinematics. J Biomech Eng, 120, 743-749, (1998). 


\title{
Effect of Knee Osteoarthritis Progression on Knee-Joint Kinematics and Kinetics during Gait
}

\author{
Ryousuke HATA ${ }^{1}$, Katsutoshi NISHINO ${ }^{2}$, Go OMORI ${ }^{3}$, \\ Yasuharu NAGANO ${ }^{4}$ and Yuji TANABE ${ }^{5}$ \\ ${ }^{1}$ Graduate School of Science and Technology, Niigata University, \\ ${ }^{2}$ Niigata Institute for Health and Sports Medicine, \\ ${ }^{3}$ Department of Health and Sports, Niigata University of Health and Welfare, \\ ${ }^{4}$ Department of Sports Wellness Sciences, Japan Women's College of Physical Education, \\ ${ }^{5}$ Department of Mechanical and Production Engineering, Niigata University
}

\begin{abstract}
Knee osteoarthritis (knee OA) is caused by abnormal knee joint mechanics. In order to prevent knee OA progression and achieve this recovery, the mechanical factors affected by knee OA during weight bearing activities, such as gait, need to be clarified. The purpose of this study was to analyze knee joint kinematics and kinetics during gait in patients with knee OA of various severities. A total of 69 knees $(62$ adults) were divided into three groups (26 normal knees, 16 mild OA knees and 27 severe OA knees). Each subject's gait was measured by a motion capture system, and the relative femorotibial motion was estimated by a bi-planar roentgenography using the three-dimensional reconstruction technique. Knee kinetics was evaluated based on joint reaction force and joint moment. The point of intersection of the loading axis of the knee(LAK) on the tibial proximal surface was also calculated, and this point was defined as the 'LAK point'. During stance phase of gait, the knee flexion range, knee anteroposterior shift and anteroposterior range of LAK-point trajectory were significantly decreased in severe OA knees, whereas the medial-lateral direction range of the knee-joint reaction force was significantly increased. The anteroposterior range of LAK-point trajectory was also small in mild OA knees. Moreover, in severe OA knees, the LAK point tended to shift rapidly medially during the loading response. As knee OA progressed, the upper body weight was more locally loaded on the tibial surface, with an increased medial-lateral force in the knee joint. These findings suggest that mechanical transitions may be affected knee OA progression.
\end{abstract}

Key Words : Osteoarthritis, Gait, Knee joint, Kinematics, Kinetics 